\title{
Comparative effects of ethanol leaf and stem bark extracts of Irvingia gabonensis (BUSH MANGO) on sodium arsenite- induced lipid profile perturbtions in wistar rats
}

\author{
Efosa Godwin Ewere ${ }^{1,2^{*}}$ (D), Ngozi Paulinus Okolie ${ }^{1}$, Erhunmwunsee Dalton Avan ${ }^{1}$ and Patience Edet Umoh ${ }^{2}$
}

\begin{abstract}
Background: Exposure to arsenic orchestrates a myriad of noxious health effects, including cancer. Different parts of Irvingia gabonensis are used as herbal remedies in traditional medicine. In this study, the comparative effects of the ethanol leaf (ELEIG) and stem bark extracts (ESEIG) of Irvingia gabonensis on sodium arsenite (SA)-induced lipid profile disturbances in Wistar rats were investigated.
\end{abstract}

Methods: Fifty five Wistar rats weighing between $100 \mathrm{~g}$ and $179 \mathrm{~g}$ were distributed into eleven groups $(n=5)$. Group 1 (control) received feed and water ad libitum. Group 2 received SA at a dose of $4.1 \mathrm{mg} / \mathrm{kg}$ body weight (kgbw) for 14 days. Groups 3-11 were treated with the extracts with or without SA. Treatment was done by oral intubation for 14 days. Serum concentrations of total cholesterol (TC), triacylglycerol (TAG), high density lipoprotein cholesterol $(H D L-c)$, low density lipoprotein cholesterol $(L D L-c)$, very low density lipoprotein cholesterol (VLDL-c), total lipids (TL) and atherogenic index of plasma (AIP) were used to determine the lipid profile effects of the extracts.

Results: Exposure to SA caused significant $\left(p^{<} 0.05\right)$ increases in all assayed parameters, relative to control. Posttreatment and simultaneous treatment with ELEIG and ESEIG mitigated the effects of SA. In addition, ELEIG alone at various doses produced results comparable with control values. However, ESEIG alone caused significant $\left(p^{<} 0.05\right.$ ) increases in all assayed parameters, relative to control.

Conclusion: These results show that ELEIG and ESEIG ameliorate SA-induced lipid profile disturbances in Wistar rats. However, long-term administration of ESEIG alone may be discouraged.

Keywords: Irvingia gabonensis, Sodium arsenite, Lipid profile, Cholesterol, Arsenic, Environmental pollutant

\section{Background}

The environment plays a vital role in the wellbeing of humans and animals. However, a distortion in the environment by environmental pollutants can negatively impact the health of its occupants (humans and animals).

\footnotetext{
* Correspondence: efosaewere@yahoo.com

${ }^{1}$ Biochemistry Department, University of Benin, Benin City, Edo State, Nigeria ${ }^{2}$ Biochemistry Department, University of Uyo, Uyo, Akwa Ibom State, Nigeria
}

Several heavy metals (such as arsenic, cadmium and lead) are established environmental pollutants which have been linked to the etiologies of diverse disease conditions [1]. Arsenic occurs at high concentrations in ground water of different countries around the World, including Nigeria [2-4]. Reports also have it that an estimated 200 million people all over the World are at health risks associated with high arsenic concentrations

\section{Springer Open}

(๑) The Author(s). 2021 Open Access This article is licensed under a Creative Commons Attribution 4.0 International License, which permits use, sharing, adaptation, distribution and reproduction in any medium or format, as long as you give appropriate credit to the original author(s) and the source, provide a link to the Creative Commons licence, and indicate if changes were made. The images or other third party material in this article are included in the article's Creative Commons licence, unless indicated otherwise in a credit line to the material. If material is not included in the article's Creative Commons licence and your intended use is not permitted by statutory regulation or exceeds the permitted use, you will need to obtain permission directly from the copyright holder. To view a copy of this licence, visit http://creativecommons.org/licenses/by/4.0/. 
in drinking water [5, 6]. Epidemiological studies have also revealed that exposure to inorganic arsenicals (e.g. arsenite) majorly via occupational and environmental exposure, is detrimental to health $[7,8]$.

As the popular saying goes "health is wealth". In the quest of ensuring a good health condition, many plants of acclaimed medicinal values have been used over the years by most locals and herbal medicine practitioners for therapeutic purposes especially those in low income countries. Irvingia gabonensis (also called bush mango or wild mango) is a plant used in traditional and modern medicine in treating various disease conditions $[9,10]$. The aqueous maceration of the leaves is used as antidote against poisonous substances. In Senegal, the decoction of the stem bark is used in treating gonorrhea, liver and gastrointestinal disorders [11]. Other medicinal properties have also been attributed to the stem bark [11-13]. Furthermore, the stem bark and leaf extracts have been reported to possess hematological, hepatoprotective, anti-diabetic and prophylactic effects in animal models [14-17]. Ewere and co-workers [18-20] have also documented the medicinal effect of leaf extracts of Irvingia gabonensis under conditions of induced toxicities in Wistar rats. However, there is a dearth of scientific information on the effect of leaf and stem bark extracts of Irvingia gabonensis on lipid profile in sodium arseniteintoxicated experimental animal models.

\section{Materials and methods}

\section{Chemicals and reagents}

Assay kits for lipid profile (total cholesterol (TC), triacylglycerol (TAG), high density lipoprotein cholesterol (HDL-c), low density lipoprotein cholesterol (LDL-c), very low density lipoprotein cholesterol (VLDL-c) and total lipids (TL) concentrations) were purchased from Sunlong Biotech co. (Shangyi, Hangzhou, Zhejiang, China). Sodium arsenite was purchased from British Drug House (BDH) chemicals, Poole, England. Absolute ethanol was purchased from JHD, China. All other chemicals / reagents used in this study were of analytical grade.

\section{Preparation of plant extracts}

Fresh leaves and stem bark of I. gabonensis were sourced from a local community in Akwa Ibom State, Nigeria. The samples were authenticated (James Daniel UUH 042116 (Uyo)) by a taxonomist of the Department of Pharmacognosy and Herbal Medicine, University of Uyo, Nigeria. They were washed using clean water to eliminate contaminants, before air-drying for 1 week in Biochemistry laboratory, University of Uyo, Nigeria. They were then pulverized using a clean manual grinder (leaves), mortar and pestle (stem).
About $850 \mathrm{~g}$ and $2800 \mathrm{~g}$ of pulverized leaves and stem bark, respectively, were macerated in absolute ethanol for $72 \mathrm{~h}$ with intermittent stirring to ensure proper extraction of the bioactive agents. The samples were filtered repeatedly through a clean muslin cloth and the filtrates were concentrated using a water bath at $45^{\circ} \mathrm{C}$. The paste-like gel extracts obtained after concentration were stored in a refrigerator at $4{ }^{\circ} \mathrm{C}$ prior to use.

\section{Experimental animals}

Fifty-five (55) healthy, non-pregnant female Wistar rats (body weights between $100 \mathrm{~g}$ and $179 \mathrm{~g}$ ) were obtained at the animal house facility of Faculty of Basic Medical Sciences, University of Uyo, Nigeria. They had free access to feed and water, and were acclimatized for seven (7) days in the same facility in a well ventilated room under standard conditions.

\section{Experimental design}

After acclimatization and just before treatment commenced, the experimental animals were randomly assigned to eleven groups $(n=5)$ in standard experimental animal cages and weighed using a digital weighing balance (Camry electronic scale EK5350, China) after overnight fast to get their initial body weights. They were administered treatment as shown in Table 1.

\section{Collection of blood samples for analysis}

On termination of treatment, all experimental animals were subjected to overnight fast with access to water only. They were chloroform-anesthetized and sacrificed using lower abdominal incision about $24 \mathrm{~h}$ after the last treatment. Whole blood samples were obtained by cardiac puncture using sterile syringes and needles and collected in sterile plain sample bottles for biochemical analysis. Sera were obtained from clotted blood samples in the plain bottles after centrifugation using a table top centrifuge (Model 800-1, Zeny Inc. Salt Lake, USA) at $3000 \mathrm{rpm}$ for $15 \mathrm{~min}$. The separated sera were preserved in a refrigerator at $4{ }^{\circ} \mathrm{C}$ prior to analyses.

\section{Biochemical analyses}

Serum total cholesterol (TC) concentration was determined according to the method of Beaumont et al. [21]. Serum triacylglycerol (TAG) concentration was determined according to the method of Fossati [22]. Serum HDL-c concentration was determined according to the method of Warnick et al. [23]. Serum LDL-c concentration was determined according to the method of Badimon et al. [24]. Serum VLDL-c concentration determination was done using the Friedewald equation (Friedewald et al. [25]. Serum total lipid concentration was determined according to the method of Frings and 
Table 1 Experimental Design

\begin{tabular}{|c|c|}
\hline Groups & Treatment \\
\hline 1. (Normal control) & feed and water ad libitum \\
\hline 2. & $4.1 \mathrm{mg} / \mathrm{kgbw}$ of SA for 14 days \\
\hline 3. & Treated with $4.1 \mathrm{mg} / \mathrm{kgbw}$ of SA for 14 days, followed by $100 \mathrm{mg} / \mathrm{kgbw}$ of extract for another 14 days \\
\hline 4. & Treated with $4.1 \mathrm{mg} / \mathrm{kgbw}$ of SA for 14 days, followed by $200 \mathrm{mg} / \mathrm{kgbw}$ of extract for another 14 days \\
\hline 5. & Treated with $4.1 \mathrm{mg} / \mathrm{kgbw}$ of SA for 14 days, followed by $400 \mathrm{mg} / \mathrm{kgbw}$ of extract for another 14 days \\
\hline 6. & Treated with $4.1 \mathrm{mg} / \mathrm{kgbw}$ of SA $+100 \mathrm{mg} / \mathrm{kgbw}$ of extract simultaneously for 14 days \\
\hline 7. & Treated with $4.1 \mathrm{mg} / \mathrm{kgbw}$ of SA $+200 \mathrm{mg} / \mathrm{kgbw}$ of extract simultaneously for 14 days \\
\hline 8. & Treated with $4.1 \mathrm{mg} / \mathrm{kgbw}$ of SA $+400 \mathrm{mg} / \mathrm{kgbw}$ of extract simultaneously for 14 days \\
\hline 9. & Treated with $100 \mathrm{mg} / \mathrm{kgbw}$ of extract for 14 days \\
\hline 10. & Treated with $200 \mathrm{mg} / \mathrm{kgbw}$ of extract for 14 days \\
\hline 11. & Treated with $400 \mathrm{mg} / \mathrm{kgbw}$ of extract for 14 days \\
\hline
\end{tabular}

SA Sodium arsenite; $\mathrm{mg} / \mathrm{kg} b \mathrm{w}$ milligram per kilogram body weight

Dunn [26] and Atherogenic index of plasma (AIP) of the samples was calculated by using the formula:

$$
\begin{aligned}
& \text { Atherogenic index of plasma (AIP) } \\
& =\frac{\text { Triacylglycerol (TAG) }}{\text { High Density Lipoprotein }}
\end{aligned}
$$

\section{Statistical analysis}

Data obtained are presented as mean \pm standard deviation (SD) and were analysed with one-way analysis of variance (ANOVA) for differences between groups using SPSS Software (IBM, version 20). $P$ values < 0.05 were considered statistically significant.

\section{Results}

\section{Effect of ELEIG on lipid profile of experimental rats}

Results obtained revealed that intoxication with SA led to significant $(p<0.05)$ increases in TC, TAG, HDL-c, LDL-c, VLDL-c, TL and AIP when compared with control. Post-treatment with ELEIG at various doses, produced significant $\left(p^{<} 0.05\right)$ and non-significant $\left(p^{>} 0.05\right)$ decreases in the concentrations of the assayed parameters, in dose-dependent and independent manner, relative to group 2 (administered SA only). Simultaneous treatment with ELEIG at various doses, took similar trend as the post-treatment. In addition, treatment with ELEIG alone at various doses, led to no-significant $(p$ ) 0.05) differences in TC, HDL-c, VLDL-c (at doses of $200 \mathrm{mg} / \mathrm{kgbw}$ and $400 \mathrm{mg} / \mathrm{kgbw}$ ), as well as TAG (at $200 \mathrm{mg} / \mathrm{kgbw}$ ), LDL-c (at $100 \mathrm{mg} / \mathrm{kgbw}$ ) and AIP (at doses of $100 \mathrm{mg} / \mathrm{kgbw}$ and $200 \mathrm{mg} / \mathrm{kgbw}$ ) relative to control. Treatment with ELEIG alone also produced significant $(p<0.05)$ decreases in LDL-c (at doses of 200 $\mathrm{mg} / \mathrm{kgbw}$ and $400 \mathrm{mg} / \mathrm{kgbw}$ ). It also produced significant $(p<0.05)$ increases in TL at various doses, relative to control.
Effect of ESEIG on lipid profile of experimental rats

Post-treatment with ESEIG at various doses, produced significant $(p<0.05)$ and non-significant $(p>0.05)$ decreases in the concentrations of the assayed parameters, in dose-dependent manner, relative to group 2 (administered SA only), except AIP. Simultaneous treatment with ESEIG at various doses followed similar trend as the post-treatment, except AIP. However, treatment with ESEIG alone at various doses, led to significant increases in all the assayed parameters, relative to control. The detailed results are presented in Tables 2 and 3, respectively.

\section{Discussion}

Documented evidence have shown that environmental pollutants such as heavy metals play a key role in the development of dyslipidemia [27, 28]. A prevalence of cardiovascular diseases such as hypertension, atherosclerosis, and heart diseases among others, has also been reported in arsenic-exposed populations [29, 30]. Wade and co-workers [31] had reported an association between cardiovascular diseases and moderate arsenic exposure among subjects in China. Other epidemiological studies have also reported the association between arsenic and cardiovascular diseases [3234]. It is therefore a possibility that arsenic poisoning may orchestrate the development of cardiovascular diseases via modification of lipid metabolism. A disturbance of the normal concentrations of key lipids: total cholesterol (TC), triacylglycerol (TAG), high density lipoprotein (HDL), low density lipoprotein (LDL), very low density lipoprotein (VLDL) and total lipid, is reflective of ill health [20].

In this study, administration of sodium arsenite alone produced significant increases in serum concentrations of total cholesterol (TC), triacylglycerol (TAG), HDL-c, LDL-c, VLDL-c and total lipids, compared with control. 
Table 2 Effect of ELEIG on Lipid Profile of Experimental Rats

\begin{tabular}{|c|c|c|c|c|c|c|c|}
\hline Groups / Treatment & $\mathrm{TC}(\mathrm{mg} / \mathrm{dL})$ & TAG (mg/dL) & $\mathrm{HDL}(\mathrm{mg} / \mathrm{dL})$ & $\mathrm{LDL}(\mathrm{mg} / \mathrm{dL})$ & VLDL (mg/dL) & Total lipid (mg/dL) & AIP (TAG/HDL) \\
\hline 1. Control & $37.80 \pm 8.84^{\text {bdfhi }}$ & $21.80 \pm 4.55^{\text {bcdfgik }}$ & $27.80 \pm 2.17^{\text {bcdefghi }}$ & $62.20 \pm 5.54^{\text {bcdjk }}$ & $7.56 \pm 1.77^{\text {bdfhi }}$ & $63.00 \pm 17.82^{\text {bcdefghijk }}$ & $-0.11 \pm 0.07^{\mathrm{hk}}$ \\
\hline 2. SA only & $87.26 \pm 12.59^{\text {acdefgh }}$ & $62.76 \pm 9.93^{\text {adefgh }}$ & $65.76 \pm 12.20^{\text {adegh }}$ & $97.32 \pm 18.54^{\text {acdefgh }}$ & $17.45 \pm 2.52^{\text {acdefghijk }}$ & $163.40 \pm 20.50^{\text {adefgh }}$ & $-0.02 \pm 0.07^{g h}$ \\
\hline $\begin{array}{l}\text { 3. Post-Treatment: } \\
100 \mathrm{mg} / \mathrm{kg}\end{array}$ & $50.40 \pm 20.04^{b}$ & $55.80 \pm 5.54^{\mathrm{a}}$ & $63.00 \pm 8.00^{\mathrm{a}}$ & $78.60 \pm 9.07^{\mathrm{ab}}$ & $10.08 \pm 4.01^{b}$ & $155.20 \pm 11.95^{\mathrm{a}}$ & $-0.05 \pm 0.09$ \\
\hline $\begin{array}{l}\text { 4. Post-Treatment: } \\
200 \mathrm{mg} / \mathrm{kg}\end{array}$ & $62.50 \pm 7.72^{\mathrm{ab}}$ & $47.50 \pm 7.05^{\mathrm{ab}}$ & $48.50 \pm 5.45^{\mathrm{ab}}$ & $47.75 \pm 3.10^{\mathrm{ab}}$ & $12.50 \pm 1.54^{\mathrm{ab}}$ & $132.75 \pm 14.38^{\mathrm{ab}}$ & $-0.01 \pm 0.07$ \\
\hline $\begin{array}{l}\text { 5. Post-Treatment: } \\
400 \mathrm{mg} / \mathrm{kg}\end{array}$ & $33.20 \pm 7.36^{b}$ & $30.20 \pm 2.59^{b}$ & $41.00 \pm 4.85^{\mathrm{ab}}$ & $52.20 \pm 14.45^{b}$ & $6.64 \pm 1.47^{b}$ & $120.20 \pm 10.99^{\mathrm{ab}}$ & $-0.13 \pm 0.06$ \\
\hline $\begin{array}{l}\text { 6. Simultaneous: } \\
100 \mathrm{mg} / \mathrm{kg}\end{array}$ & $70.66 \pm 5.82^{\mathrm{ab}}$ & $46.60 \pm 5.03^{\mathrm{ab}}$ & $58.50 \pm 4.98^{\mathrm{a}}$ & $71.86 \pm 6.24^{b}$ & $14.13 \pm 1.16^{\mathrm{ab}}$ & $130.20 \pm 6.06^{\mathrm{ab}}$ & $-0.10 \pm 0.08$ \\
\hline $\begin{array}{l}\text { 7. Simultaneous: } \\
200 \mathrm{mg} / \mathrm{kg}\end{array}$ & $39.25 \pm 8.18^{b}$ & $32.00 \pm 11.17^{\mathrm{ab}}$ & $49.03 \pm 5.39^{\mathrm{ab}}$ & $55.50 \pm 8.61^{b}$ & $7.85 \pm 1.64^{b}$ & $128.50 \pm 11.68^{\mathrm{ab}}$ & $-0.20 \pm 0.18^{b}$ \\
\hline $\begin{array}{l}\text { 8. Simultaneous: } \\
400 \mathrm{mg} / \mathrm{kg}\end{array}$ & $57.50 \pm 7.42^{\mathrm{ab}}$ & $25.83 \pm 12.03^{b}$ & $55.48 \pm 4.19^{\mathrm{ab}}$ & $52.75 \pm 11.95^{b}$ & $11.50 \pm 1.48^{\mathrm{ab}}$ & $92.00 \pm 30.85^{\mathrm{ab}}$ & $-0.39 \pm 0.26^{a b}$ \\
\hline $\begin{array}{l}\text { 9. ELEIG only: } \\
100 \mathrm{mg} / \mathrm{kg}\end{array}$ & $55.00 \pm 8.69^{\mathrm{a}}$ & $38.78 \pm 3.21^{\mathrm{a}}$ & $53.80 \pm 6.98^{\mathrm{a}}$ & $51.46 \pm 11.22$ & $11.00 \pm 1.74^{\mathrm{a}}$ & $103.70 \pm 13.85^{\mathrm{a}}$ & $-0.14 \pm 0.06$ \\
\hline $\begin{array}{l}\text { 10. ELEIG only: } \\
200 \mathrm{mg} / \mathrm{kg}\end{array}$ & $40.40 \pm 8.11$ & $30.46 \pm 4.43$ & $35.08 \pm 4.48$ & $48.80 \pm 9.58^{\mathrm{a}}$ & $8.08 \pm 1.62$ & $102.80 \pm 13.68^{\mathrm{a}}$ & $-0.06 \pm 0.08$ \\
\hline $\begin{array}{l}\text { 11. ELEIG only: } \\
400 \mathrm{mg} / \mathrm{kg}\end{array}$ & $50.80 \pm 11.17$ & $34.80 \pm 5.12^{\mathrm{a}}$ & $28.24 \pm 5.88$ & $48.54 \pm 4.25^{\mathrm{a}}$ & $10.16 \pm 2.23$ & $99.52 \pm 8.73^{\mathrm{a}}$ & $-0.09 \pm 0.12^{\mathrm{a}}$ \\
\hline
\end{tabular}

Table 3 Effect of ESEIG on Lipid Profile of Experimental Rats

\begin{tabular}{|c|c|c|c|c|c|c|c|}
\hline Groups / Treatment & $\mathrm{TC}(\mathrm{mg} / \mathrm{dL})$ & TAG (mg/dL) & $\mathrm{HDL}(\mathrm{mg} / \mathrm{dL})$ & $\mathrm{LDL}(\mathrm{mg} / \mathrm{dL})$ & VLDL (mg/dL) & $\begin{array}{l}\text { Total lipid (mg/ } \\
\mathrm{dL})\end{array}$ & AIP (TAG/HDL) \\
\hline 1. Control & $\begin{array}{l}30.00 \pm \\
3.81^{\text {bcdefghijk }}\end{array}$ & $\begin{array}{l}25.40 \pm 7.33 \\
\text { bcdefghijk }\end{array}$ & $\begin{array}{l}43.00 \pm \\
7.97^{\text {bcdghijk }}\end{array}$ & $\begin{array}{l}38.20 \pm 9.44 \\
\text { bcdefghijk }\end{array}$ & $\begin{array}{l}5.08 \pm 1.47 \\
\text { bcdefghijk }\end{array}$ & $\begin{array}{l}62.00 \pm 6.32 \\
\text { bcdefghijk }\end{array}$ & $\begin{array}{l}-0.24 \pm \\
0.18^{\text {bcdefghijk }}\end{array}$ \\
\hline 2. SA only & $\begin{array}{l}95.00 \pm \\
6.58^{\text {acdefgh }}\end{array}$ & $64.50 \pm 5.00^{\text {acdef }}$ & $\begin{array}{l}70.50 \pm \\
10.28^{\text {adefg }}\end{array}$ & $\begin{array}{l}125.25 \pm 13.94 \\
\text { acdefgh }\end{array}$ & $12.90 \pm 1.00^{\text {acdef }}$ & $\begin{array}{l}182.75 \pm 8.66 \\
\text { acdefgh }\end{array}$ & $-0.04 \pm 0.08^{\mathrm{a}}$ \\
\hline $\begin{array}{l}\text { 3. Post Treatment: } \\
100 \mathrm{mg} / \mathrm{kg}\end{array}$ & $68.40 \pm 9.24^{\mathrm{ab}}$ & $51.80 \pm 3.27^{\mathrm{ab}}$ & $63.40 \pm 7.30^{\mathrm{a}}$ & $68.60 \pm 5.41^{\mathrm{ab}}$ & $10.36 \pm 0.65^{\mathrm{ab}}$ & $146.20 \pm 9.47^{\mathrm{ab}}$ & $-0.09 \pm 0.07^{a}$ \\
\hline $\begin{array}{l}\text { 4. Post Treatment: } \\
200 \mathrm{mg} / \mathrm{kg}\end{array}$ & $58.40 \pm 3.51^{\mathrm{ab}}$ & $50.00 \pm 1.58^{\mathrm{ab}}$ & $57.60 \pm 6.95^{\mathrm{ab}}$ & $68.80 \pm 6.50^{a b}$ & $10.00 \pm 0.32^{\mathrm{ab}}$ & $133.60 \pm 7.23^{\mathrm{ab}}$ & $-0.06 \pm 0.04^{\mathrm{a}}$ \\
\hline $\begin{array}{l}\text { 5. Post Treatment: } \\
400 \mathrm{mg} / \mathrm{kg}\end{array}$ & $51.25 \pm 8.06^{\mathrm{ab}}$ & $42.00 \pm 4.08^{\mathrm{ab}}$ & $47.25 \pm 7.97^{b}$ & $59.50 \pm 4.80^{\mathrm{ab}}$ & $8.40 \pm 0.82^{\mathrm{ab}}$ & $117.75 \pm 6.70^{\mathrm{ab}}$ & $-0.05 \pm 0.06^{a}$ \\
\hline $\begin{array}{l}\text { 6.Simultaneous: } \\
100 \mathrm{mg} / \mathrm{kg}\end{array}$ & $72.00 \pm 6.06^{\mathrm{ab}}$ & $45.25 \pm 6.45^{\mathrm{ab}}$ & $51.50 \pm 8.50^{\mathrm{b}}$ & $58.75 \pm 3.59^{\mathrm{ab}}$ & $9.05 \pm 1.29^{\mathrm{ab}}$ & $122.50 \pm 11.39^{\mathrm{ab}}$ & $-0.06 \pm 0.04^{a}$ \\
\hline $\begin{array}{l}\text { 7.Simultaneous: } 200 \\
\mathrm{mg} / \mathrm{kg}\end{array}$ & $74.25 \pm 6.70^{\mathrm{ab}}$ & $60.00 \pm 6.68^{\mathrm{a}}$ & $58.50 \pm 10.47^{\mathrm{ab}}$ & $62.50 \pm 12.45^{\mathrm{ab}}$ & $12.00 \pm 1.34^{\mathrm{a}}$ & $126.75 \pm 3.77^{\mathrm{ab}}$ & $0.02 \pm 0.13^{\mathrm{a}}$ \\
\hline $\begin{array}{l}\text { 8.Simultaneous: } 400 \\
\mathrm{mg} / \mathrm{kg}\end{array}$ & $76.33 \pm 5.69^{\mathrm{ab}}$ & $63.67 \pm 4.51^{\mathrm{a}}$ & $66.00 \pm 3.00^{\mathrm{a}}$ & $80.33 \pm 4.04^{\mathrm{ab}}$ & $12.73 \pm 0.90^{\mathrm{a}}$ & $132.67 \pm 3.06^{\mathrm{ab}}$ & $-0.02 \pm 0.02^{\mathrm{a}}$ \\
\hline $\begin{array}{l}\text { 9. ESEIG only: } 100 \mathrm{mg} / \\
\text { kg }\end{array}$ & $69.50 \pm 0.50^{\mathrm{a}}$ & $59.50 \pm 3.50^{a}$ & $62.00 \pm 2.00^{a}$ & $72.00 \pm 1.00^{\mathrm{a}}$ & $11.90 \pm 0.70^{\mathrm{a}}$ & $139.50 \pm 3.50^{\mathrm{a}}$ & $-0.02 \pm 0.04^{a}$ \\
\hline $\begin{array}{l}\text { 10. ESEIG only: } 200 \\
\mathrm{mg} / \mathrm{kg}\end{array}$ & $70.67 \pm 6.43^{\mathrm{a}}$ & $54.67 \pm 5.13^{\mathrm{a}}$ & $67.00 \pm 3.00^{\mathrm{a}}$ & $63.33 \pm 15.37^{\mathrm{a}}$ & $10.93 \pm 1.03^{\mathrm{a}}$ & $119.33 \pm 13.58^{\mathrm{a}}$ & $-0.09 \pm 0.05^{\mathrm{a}}$ \\
\hline $\begin{array}{l}\text { 11. ESEIG only: } 400 \\
\mathrm{mg} / \mathrm{kg}\end{array}$ & $71.00 \pm 2.65^{\mathrm{a}}$ & $50.00 \pm 2.65^{a}$ & $57.67 \pm 5.69^{\mathrm{a}}$ & $65.67 \pm 7.37^{\mathrm{a}}$ & $10.00 \pm 0.53^{\mathrm{a}}$ & $113.00 \pm 8.89^{\mathrm{a}}$ & $-0.06 \pm 0.06^{\mathrm{a}}$ \\
\hline
\end{tabular}

Data are expressed as mean $\pm \mathrm{SD}(\mathrm{n}=5){ }^{\text {a }} p^{<} 0.05$ compared with group $1 ;{ }^{\mathrm{b}} p^{<} 0.05$ compared with group $2^{\mathrm{c}} p^{<} 0.05$ compared with group $3{ }^{\mathrm{d}} p^{<} 0.05$ compared with group $4 ;{ }^{\mathrm{e}} p^{<} 0.05$ compared with group $5 ;{ }^{\mathrm{f}} p^{<} 0.05$ compared with group $6 ;{ }^{\mathrm{g}} p^{<} 0.05$ compared with group $7 ;{ }^{\mathrm{h}} p^{<} 0.05$ compared with group 8 ; ${ }^{i} p^{<} 0.05$ compared with group $9 ;{ }^{j} p^{<} 0.05$ compared with group $10 ;{ }^{k} p^{<} 0.05$ compared with group 11; AIP= Attherogenic index of plasma; SA = Sodium arsenite 
Administration of sodium arsenite alone also produced significant and non-significant increases in atherogenic index of plasma (AIP) relative to control. Cardiovascular diseases may arise as a consequence of metabolic disorders such as dyslipidemia and diabetes [35]. Several documented evidence have linked elevation of serum cholesterol, LDL-c and triacylglycerol concentrations with the etiology of cardiovascular diseases [36-41].

Contrary to several documented reports stating decreases in HDL-c concentration in dyslipidemia, sodium arsenite intoxication produced significant increases in serum HDL-c concentration when compared with control. HDL-c is generally referred to as "good cholesterol" due to its function in reverse cholesterol transport, removing cholesterol from within the artery and transporting same back to the liver for onward excretion and utilization [42]. However, some recent studies have shown that too high HDL-c concentration may not necessarily be a good omen. There are different possible explanations to the significant increases in HDL-c observed in this study.

Firstly, HDL-c has been reported to possess antioxidant and anti-inflammatory properties [43]. It is involved in mopping up lipid hydroperoxides induced by oxidative stress. Sodium arsenite has been reported to induce oxidative stress as well as lipid peroxidation [44, 45]. The observed significant increase in HDL-c concentration in this study may have arisen in an attempt by HDL-c to mop up lipid hydroperoxides generated by sodium arsenite. Secondly, documented evidence also has it that increased HDL-c levels may be due to the inefficient clearance of LDL-c (bad cholesterol) from circulation [46]. Thirdly, oxidative stress has the capacity to modify the protective effects of HDL-c by oxidizing it, thereby making it proatherogenic rather than antiinflammatory [47-49]. Finally, the increased HDL-c may be dysfunctional HDL-c which may increase risk of premature death [50]. Pathological processes such as inflammation can overwhelm the antioxidant and antiinflammatory functions of HDL-c, converting it to a 'dysfunctional' pro-inflammatory, pro-oxidant, prothrombotic, and proapoptotic particle which may impair reverse cholesterol transport and thus predispose to cardiovascular diseases $[51,52]$.

The result obtained from this study is very vital because it contributes and agrees with a growing body of evidence that very high HDL-c levels may not be protective. According to various recent reports, very high levels of HDL-c may be associated with an increased risk of heart attack and death [50, 53, 54].

Treatment with ethanol leaf extract of Irvingia gabonensis (ELEIG) 2 weeks after (post-treatment) produced significant decreases in serum concentrations of $\mathrm{TC}$, TAG, HDL-c and total lipid in dose-dependent manner while dose-independent significant decreases were observed for LDL-c and VLDL-c, compared with group 2, administered sodium arsenite only. In addition, simultaneous treatments with ELEIG produced significant decreases in serum concentrations of TAG, LDL-c, and total lipid in dose-dependent manner while doseindependent significant decreases were observed for TC, HDL-c and VLDL-c when compared with group 2, administered sodium arsenite only. Simultaneous treatment with ELEIG at doses of $200 \mathrm{mg} / \mathrm{kgbw}$ and $400 \mathrm{mg} /$ kgbw respectively, also produced significant decreases in AIP when compared with group 2, administered sodium arsenite only. The reversal of sodium arsenite-induced dyslipidemia by ELEIG may therefore be by its mitigation of oxidative stress and inflammation induced by sodium arsenite which have been widely reported to play a key role in the etiology of cardiovascular diseases. This is possibly due to the inherent antioxidant phytochemicals present in the extract [55]. Administration of ELEIG alone at different doses also produced comparable results with that of the control.

On the other hand, treatment with ethanol stem bark extract of Irvingia gabonensis (ESEIG) both simultaneously and 2 weeks after (post-treatment) produced significant and non-significant decreases in serum concentrations of the assayed lipid profile parameters when compared with group 2, administered sodium arsenite only except AIP of the treated groups, which were not significantly different. However, administration of ESEIG alone at various doses culminated in significant increases in all assayed lipid profile parameters relative to control. Since elevations in lipid profile parameters have been associated with cardiovascular diseases, ESEIG may therefore be slightly toxic when administered solely on a long-term basis. This is in tandem with previous findings of Ewere et al. [56].

\section{Conclusion}

The results obtained from this study indicate that ethanol leaf and stem bark extracts of Irvingia gabonensis mitigate sodium arsenite-induced lipid profile perturbations in Wistar rats. Ethanol leaf of Irvingia gabonensis extract may therefore be useful in combating arsenic poisoning. However, ethanol stem bark extract of Irvingia gabonensis may be slightly toxic when administered alone on a long-term basis. Thus, long-term administration of the stem bark extract may not be encouraged.

\section{Abbreviations}

ELEIG: Ethanol leaf extract of Irvingia gabonensis; ESEIG: Ethanol stem bark extract of Irvingia gabonensis; SA: Sodium arsenite; TL: Total lipid;

AIP: Atherogenic index of plasma

\section{Acknowledgements}

We thank Derindam Research Institute of Biotechnology, Akwa Ibom State, Nigeria for allowing the use of their laboratories for this study. 


\section{Authors' contributions}

EGE and NPO designed the study. EGE performed the statistical analysis and wrote the first draft of the manuscript. NPO supervised the study. EGE managed the analyses of the study. EGE and PEU managed experimental animal treatment and literature searches. EDA and NPO were major contributors in writing the manuscript. All Authors read and approved the final manuscript.

\section{Funding}

All authors have declared that, no funding whatsoever, was received for this study.

\section{Availability of data and materials}

All data obtained from this study have been included in this article.

\section{Ethics approval}

All authors hereby declare that the "Principles of laboratory animal care" (NIH publication No. 85-23, revised 1985) were followed as well as specific national laws where applicable. All experiments have been examined and approved by the appropriate Institutional Review Board.

\section{Consent for publication}

Not applicable.

\section{Competing interests}

None exists.

\section{Received: 17 July 2020 Accepted: 23 December 2020}

\section{Published online: 03 January 202}

\section{References}

1. Kaya S, Pirincci I, Tras B, Unsal A, Bilgili A, Akar F, et al. Metals, other inorganic vet radioactive agents. In: Kaya S, Pirincci I, Bilgili A, editors. Toxicology in veterinary medicine. 2nd ed. Ankara: Medisan Press; 2002.

2. Pandey PK, Yadav S, Nair S, Bhui A. Arsenic contamination of the environment: a new perspective from central-East India. Environ Int. 2002; 28:235-45.

3. Garba ZN, Gimba CE, Galadima A. Arsenic contamination of domestic water from Nothern Nigeria. Int J Sci Technol. 2012;2(1):55-60.

4. Ezeabasili ACC, Anike OL, Okoro BU, Dominic CM. Arsenic pollution of surface and subsurface water in Onitsha, Nigeria. Afr J Environ Sci Technol. 2014,8:491-7.

5. NRC (National Research Council). Subcommittee to Update the 1999 Arsenic in drinking water report. Washington DC: National Academy Press; 2001

6. Ravenscroft P, Brammer H, Richards K. Arsenic Pollution: A Global Synthesis, Chichester UK, RGS-IBG Book Series, Wiley-Blackwell; 2009.

7. IARC. Some Drinking-water Disinfectants and Contaminants, including Arsenic. IARC Monographs on the Evaluation of Carcinogenic Risks to Humans, vol. 84; 2004. p. 1-477.

8. Arteel GE, Guo L, Schlierf T, Beier Jl, Kaiser JP, Chen TS, et al. Subhepatotoxic exposure to arsenic enhances lipopolysaccharide-induced liver injury in mice. Toxicol Appl Pharmacol. 2008;226:128-39.

9. Lowe AJ, Gillies ACM, Wilson J, Dawson IK. Conservation genetics of bush mango from central/West Africa: Implica-tions for RAPD analysis. Mol Ecol. 2000;9:831-41.

10. Anegbeh PO, Usoro C, Ukafor V, Tchoundjeu Z, Leakey RRB, Schreckenberg K. Domestication of Irvingia gabonensis 3: phenotypic variation of fruits and kernels in a Nigeria village. Agrofor Syst. 2003;58:213-8.

11. Hubert DJ, Wabo FG, Ngameni B, Ngheguin TF, Tchoukoua A, Ambassa P, et al. In vitro Hepatoprotective and antioxidant activities of the crude extract and isolated compounds from Irvingia gabonensis. Asian J Traditional Med. 2010;5:79-88.

12. Kuete V, Wabo GF, Ngameni B, Mbaveng AT, Metuno R, Etoa FX, et al. Antimicrobial activity of the Methanolic extract, fractions and compounds from the stem bark of Irvingia gabonensis (Ixonanthaceae). J Ethnopharmacol. 2007:114:54-60.

13. Etta HE, Olisaeke CC, Iboh Cl. Effect of Irvingia gabonensis (Aubry-Lecomte ex O'Rorke) seeds on the liver and gonads of male albino rats. J Biol Agric Healthcare. 2014;4:10-5.
14. Omonkhua AA, Onoagbe IO. Effects of long-term oral administration of aqueous extracts of Irvingia gabonensis bark on blood glucose and liver profile of normal rabbits. J Med Plant Res. 2012;6:2581-9.

15. Omonkhua AA, Onoagbe IO, Fajimey IA, Adekola MB, Imoru ZA. Long-term anti-diabetic and anti-hyperlipidaemic effects of aqueous stem bark extract of Irvingia gabonensis in streptozotocin-induced diabetic rats. Biokemistri. 2014;2:1-8.

16. Ojo OA, Ajoboye BO, Oyinloye BE, Ojo AB. Prophylactic effects of Ethanolic extract of Irvingia gabonensis stem bark against cadmium-induced toxicity in albino rats. Adv Pharmaceutical Bull. 2014;2014:1-8.

17. Nubila T, Ukaejiofo EO, Nubila NI, Shu EN, Okwuosa CN, Okofu MB, et al. Sub-acute effects of crude methanolic leaf extract of Irvingia gabonensis (Aubry- Lecomte et O'Rorke Baill) on activated partial thromboplastin time, prothrombin time and platelet values in albino wistar rats. Nigerian J Exp Clin Biosci. 2014:2(2):75-8.

18. Ewere EG, Oyebadejo SA, Peter VC. Ethanolic leaf extract of Irvingia gabonensis ( $\mathrm{O}^{\prime}$ Rorke) Baill protects against nephrotoxicity and Hepatotoxocity in cadmium-induced Wistar albino rats. Int J Pharmacol Toxicol. 2016:4:105-10.

19. Ewere EG, Etim OE, Oyebadejo SA, Edem BV. Attenuation of cadmiuminduced Haematological derangements in Wistar albino rats by Irvingia gabonensis O'Rorke Baill ethanol leaf extract. Eur J Biomed Pharm Sci. 2017; 4:169-74.

20. Ewere EG, Anwana UIU, Oyebadejo SA. Irvingia gabonensis ethanol leaf extract mitigates cadmium-induced hypolipidaemia in wistar albino rats. J Environ Life Sci. 2018:3:17-24.

21. Beaumont $J$, Crison LA, Cooper GR, Feifar Z, Frederickson DS, Strasser T. Classification of hyperlipidemias and Hyperlipoproteinemias. Standard methods of clinical chemistry Vol. 9. New YorkNY: Academic Press; 1972.

22. Fossati $P$, Prencipe L. Serum triglycerides determined colorimetrically with an enzyme that produces hydrogen peroxide. Clin Chem. 1982;28(10):2077-80.

23. Warnick GR, Albers J. A comprehensive evaluation of the heparinmanganese precipitation procedure for estimating high density lipoprotein cholesterol. J Lipid Res. 1978;19(1):65-76.

24. Badimon JJ, Badimon L, Fuester V. Regression of Athroscierotic lesions by high-density lipoprotein plasma fraction in the cholesterol-fed rabbit. J Clin Investig. 1990;85:1234-41.

25. Friedewald WT, Levy RI, Fredrickson DS. Estimation of the concentration of low density lipoprotein cholesterol in plasma, without use of the preparative ultracentrifuge. Clin Chem. 1972;18:499-502.

26. Frings CS, Dunn RT. A colorimetric method for determination of total serum lipids based on the sulfo-phospho-vanillin reaction. Am J Clin Pathol. 1970:53(1):89-91.

27. Ademuyiwa O, Ugbaja RN, Idumebor F, Adebawo OO. Plasma lipid profiles and risk of cardiovascular disease in occupational lead exposure in Abeokuta, Nigeria. Lipids Health Dis. 2005:4(1):19.

28. Prozialeck WC, Edwards JR, Nebert DW, Woods JM, Barchowsky A, Atchison WD. The vascular system as a target of metal toxicity. Toxicol Sci. 2008;102: 207-18

29. States JC, Srivastava S, Chen Y, Barchowsky A. Arsenic and cardiovascular disease. Toxicol Sci. 2009;107:312-23.

30. Mazumder DG, Dasgupta UB. Chronic arsenic toxicity: studies in West Bengal. India Kaohsiung J Med Sci. 2011;27:360-70

31. Wade TJ, Xia Y, Mumford J, Wu K, Le XC, Sams E, et al. Cardiovascular disease and arsenic exposure in Inner Mongolia, China: a case control study. Environ Health. 2015;14:1-10.

32. Bianchi F, Cori L, Sicari R. Arsenic and cardiovascular diseases. E3S Web Conferences. 2013:1:1-2

33. Moon K, Guallar E, Navas-Acien A. Arsenic exposure and cardiovascular disease: an updated systematic review. Curr Atherosclerosis Rep. 2012;14:542-55.

34. Chen Y, Wu F, Liu M, Parvez F, Slavkovich V, Eunus M, et al. A prospective study of arsenic exposure, arsenic methylation capacity, and risk of cardiovascular disease in Bangladesh. Environ Health Perspective. 2013; 121(7):832-8.

35. Zhang W, Fievez $L$, Cheu E, Bureau F, Rong W. Anti-inflammatory effects of formoterol and ipratropium bromide against acute cadmium-induced pulmonary inflammation in rats. Eur J Pharmacol. 2010;628:171-8.

36. Superko HR, Nejedly M, Garrett B. Small LDL and its clinical importance as a new CAD risk factor: a female case study. Prog Cardiovasc Nurs. 2002:4:167-73.

37. Barter P, Gotto AM, Maroni JC, Szarek J, Grundy SM, Kastelein JP, et al. HDL cholesterol, VLDL cholesterol and cardiovascular events. N Engl J Med. 2007 357:1301-9. 
38. Nordestgaard BG, Varbo A. Triglycerides and cardiovascular disease. Lancet. 2014;384:626-35

39. Dhingra D, Lamba D, Kumar R, Nath P, Gauttam S. Antihyperlipidemic activity of Aloe succotrina in rats: possibly mediated by inhibition of HMGCoA Reductase. ISRN Pharmacol. 2014;2014:1-9.

40. Haque ATME, Yusoff FBM, Ariffin MHS, Hamid MF, Hashim SRB, Haque M. Lipid profile of the coronary heart disease (CHD) patients admitted in a Hospital in Malaysia. J Appl Pharmaceutical Sci. 2016;6:137-42.

41. Lee JS, Chang P, Zhang Y, Kizer JR, Best LG, Howard BV. Triglyceride and HDL-C dyslipidemia and risks of coronary heart disease and ischemic stroke by glycemic Dysregulation status: the strong heart study. Diabetes Care. 2017;40:529-37.

42. Lin M, Hoke C, Ettinger B. Evaluation of homogeneous high-density lipoprotein cholesterol assay on a BM/Hitachi 747-200 analyzer. Clin Chem. 1998:5:1050-4

43. Shao B, Heinecke JW. (2009). HDL, lipid peroxidation, and atherosclerosis. J Lipid Res. 2009;50:599-601.

44. Flora SJ, Mittal M, Gupta R, Pant SC. Arsenic Toxicity: Biochemical Effects, Mechanism of Action and strategies for the prevention and treatment by Chelating Agents and Herbal Extracts. India, I. K. International Publishing House Put. Ltd; 2010.

45. Zhang Z, Wang X, Cheng S, Sun L, Son YO, Yao H. Reactive oxygen species mediate arsenic induced cell transformation and tumorigenesis through Wnt/ß-catenin pathway in human colorectal adenocarcinoma DLD1 cells. Toxicol Appl Pharmacol. 2011;256:114-21.

46. Vergeer M, Holleboom AG, Kastelein JJP, Kuivenhoven JA. The HDL hypothesis: does high density lipoprotein protect from Atherosceloris? J Lipid Res. 2010;51:2058-73.

47. Sharma A, Sharma MK, Kumar M. Modulatory role of Emblica officinalis fruit extract against arsenic induced oxidative stress in Swiss albino mice. Chem Biology Interactions. 2009;180:20-30.

48. Rho YH, Chung CP, Oeser A, Solus JF, Gebretsadik T, Shintani A, et al. Interaction between oxidative stress and high density lipoprotein cholesterol is associated with seventy of coronary artery calcification in rheumatoid arthritis. Arthritis Care Res. 2010;62:1473-80.

49. G HB, Rao VS, Kakkar W. Friend turns foe: transformation of antiinflammatory HDL to proinflammatory HDL during acute-phase response. Cholesterology. 2011;2011:274629.

50. Bowe B, Xie Y, Xian H, Balasubramanian S, Zayed MA, Al-Aly Z. High density lipoprotein cholesterol and the risk of all cause mortality among US veterans. Clin J Am Soc Nephrol. 2016;11(10):1784-93.

51. Eren E, Yilmaz N, Aydin O. (2012). High density lipoprotein and it's dysfunction. Open Biochem J. 2012;6:78-93.

52. Serban C, Muntean D, Mikhailids DP, Toth PP, Banach M. Dysfunctional HDL: the journey from savior to slayer. Clin Lipidol. 2014;9:49-59.

53. Washington University in St. Louis. High and Low levels of 'good cholesterol' may cause premature death. ScienceDaily. 2016. www. sciencedaily.com/releases/2016/08/160811190922.htm. Acessed September 3,2018

54. European Society of Cardiology. Too much of a good thing? Very high levels of 'good' cholesterol may be harmful. ScienceDaily. 2018. www. sciencedaily.com/releases/2018/08/180825081724.htm. Accessed April 22, 2019.

55. Ewere EG, Uka E, Usunobun U. Phytochemical composition, in vitro antioxidant activity and acute toxicity of Irvingia gabonensis (O'Rorke) Baill Ethanolic leaf extract. Int J Biol Res. 2016;4:36-41.

56. Ewere EG, Okolie NP, Eze Gl, Oyebadejo SA. Effect of Irvingia gabonensis stem bark on liver function in sodium Arsenite-exposed Wistar rats. J Asian Sci Res. 2019;9(8):81-94.

\section{Publisher's Note}

Springer Nature remains neutral with regard to jurisdictional claims in published maps and institutional affiliations.

\section{Submit your manuscript to a SpringerOpen ${ }^{\circ}$ journal and benefit from:}

- Convenient online submission

- Rigorous peer review

- Open access: articles freely available online

- High visibility within the field

- Retaining the copyright to your article

Submit your next manuscript at $\boldsymbol{\nabla}$ springeropen.com 